\title{
Characterization of Dielectric Barrier Discharge Atmospheric Air Plasma Treated Chitosan Films
}

\author{
Shashi Pankaj \\ Technological University Dublin, shashi.pankaj@tudublin.ie \\ Carmen Bueno-Ferrer \\ Technological University Dublin, Ireland, carmen.buenoferrer@tudublin.ie \\ Luke O'Neill \\ Technological University Dublin, Luke.oneill@tudublin.ie
}

See next page for additional authors

Follow this and additional works at: https://arrow.tudublin.ie/schfsehart

Part of the Chemistry Commons, Food Science Commons, and the Medicine and Health Sciences

\section{Commons}

\section{Recommended Citation}

Pankaj, Shashi \& Bueno-Ferrer, Carmen \& O Neill, Luke \& Brijesh kumar, Tiwari \& Bourke, Paula \& Cullen, P.J. (2016). Characterization of Dielectric Barrier Discharge Atmospheric Air Plasma Treated Chitosan Films: DBD Plasma Treatment of Chitosan Film. Journal of Food Processing and Preservation. 41. 10.1111/jfpp.12889.

This Article is brought to you for free and open access by the School of Food Science and Environmental Health at ARROW@TU Dublin. It has been accepted for inclusion in Articles by an authorized administrator of ARROW@TU Dublin. For more information, please contact arrow.admin@tudublin.ie, aisling.coyne@tudublin.ie, gerard.connolly@tudublin.ie.

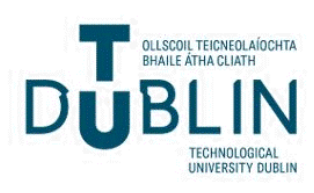




\section{Authors}

Shashi Pankaj, Carmen Bueno-Ferrer, Luke O'Neill, B.K. Tiwari, Paula Bourke, and Patrick J. Cullen 


\title{
CHARACTERIZATION OF DIELECTRIC BARRIER DISCHARGE ATMOSPHERIC AIR PLASMA TREATED CHITOSAN FILMS
}

\author{
S.K. PANKAJ, ${ }^{1}$ C. BUENO-FERRER, ${ }^{1}$ L. O'NEILL, ${ }^{2}$ B.K. TIWARI, ${ }^{3}$ PAULA BOURKE ${ }^{1}$ and P.J. CULLEN ${ }^{1,4,5}$ \\ ${ }^{1}$ BioPlasma Research group, School of Food Science and Environmental Health, Dublin Institute of Technology, Dublin 1, Ireland \\ ${ }^{2}$ FOCAS Research Institute/School of Physics, Dublin Institute of Technology, Dublin 8, Ireland \\ ${ }^{3}$ Teagasc Food Research Centre, Ashtown, Dublin, Ireland \\ ${ }^{4}$ School of Chemical Engineering, UNSW Australia, Sydney NSW 2052, Australia
}

${ }^{5}$ Corresponding author.

TEL: + 35314027595 ;

FAX: +35318788978 ;

EMAIL: pjcullen@dit.ie

Received for Publication September 18, 2015 Accepted for Publication January 25, 2016

doi:10.1111/jfpp.12889

\begin{abstract}
Dielectric barrier discharge (DBD) plasma is a novel non-thermal food decontamination technology. The effects of DBD plasma on the surface topography, chemical composition and crystal structure, film hydrophilicity, water vapor permeability and oxygen permeability of chitosan films have been examined. DBD plasma treatment increased the surface roughness of chitosan films with emergence of sharp protuberances. X-ray photoelectron spectroscopy and Fourier transform infrared spectroscopy spectra confirm a significant increase in the oxygen containing groups in the chitosan film after plasma treatment. Significant increase in the film hydrophilicity was observed after plasma treatment. X-ray diffraction results showed that DBD plasma treatment do not affect the crystal type, although an increase in the structural compactness was observed. No significant change was observed in barrier properties of the chitosan film after DBD plasma treatment.
\end{abstract}

\section{PRACTICAL APPLICATIONS}

In-package cold plasma is an innovative technology for the decontamination of foods products and has shown significant potential for industrial applications. This article accesses the suitability of chitosan film to be used with cold plasma treatment. This work characterizes the effect of DBD plasma on the surface, chemical, structural and barrier properties of chitosan film. The work described in this research offers an alternative to the traditional petro-chemical based polymers dominant in food packaging industry where in-package cold plasma can serve as an effective decontamination process avoiding any post-process recontamination or hazards from the package itself.

\section{INTRODUCTION}

A major surge in the food packaging research has been seen in the past few decades to develop and apply biobased polymers as films or coatings for fresh or processed food products. The concern over the limited natural resources and the environmental impact caused by the use of non-biodegradable plastic-based packaging materials has been the driving force to search for bio-based, non-toxic, biodegradable, low cost alternatives (Ferreira et al. 2009). Various proteins like gelatin, zein, caseinates and polysaccharides like starches, chitin/chitosan, gums and their blends have shown potential to be used as films and coatings to extend the shelf-life of food products.

Chitosan is a linear polysaccharide consisting of $(1,4)$ linked 2-amino-deoxy- $\beta$-D-glucan, is a deacetylated derivative of chitin, which is the second most abundant polysaccharide found in nature after cellulose (Aider 2010). Chitosan can be either used as edible coatings $(<30 \mu \mathrm{m})$ for direct application on food or as films $(>30 \mu \mathrm{m})$ to improve the food safety and shelf-life (van den Broek et al. 2015). Chitosan has been reported to be used for various food products like peach, pear, kiwifruit (Du 1997), strawberry (El Ghaouth et al. 
1991a), tomato (El Ghaouth et al. 1992), cucumber, bell pepper (El Ghaouth et al. 1991b), longan fruit (Jiang and Li 2001) and shrimps (Simpson et al. 1997) for extension of their quality attributes and shelf-life.

Cold plasma is one of the novel non-thermal food decontamination technologies, which has also shown potential to be used for various fresh or processed fruits, vegetables and meat products. Cold plasma can be generated by various ways and is characterized by the disequilibrium of temperature between the electrons and heavier species (Pankaj et al. 2013). Dielectric barrier discharge (DBD) is one of the common methods to generate cold plasma. In most common DBD devices, plasma is generated between two planeparallel metal electrodes among which at least one of the electrodes is covered by a dielectric layer (Pankaj et al. 2014c). Cold plasma has been used for various applications in the food packaging industry like surface sterilization, functionalization and other modifications (Pankaj et al. $2014 b$ ). The effects of plasma treatments on various conventional and bio-based polymers has already been reported previously (Upadhyay et al. 2004; Leroux et al. 2008; Bastos et al. 2009; Chang and Chian 2013; Pankaj et al. 2014d, in press a,b). This present work aims to present the effects of atmospheric air DBD plasma treatment on cast chitosan film to access its compatibility to be used as food packaging material for plasma processed food products.

\section{EXPERIMENTAL}

\section{Film Preparation}

Medium molecular weight chitosan (product code: 448877), analytical grade acetic acid and glycerol were purchased from Sigma-Aldrich, Ireland. Chitosan film was prepared by the method followed by Leceta et al. (2013) with minor modifications. Chitosan (1\% wt/vol) solution was prepared in $1 \%$ acetic acid solution. Glycerol (10\%) was added after $15 \mathrm{~min}$ continuous stirring. Stirring was continued for $30 \mathrm{~min}$ until total homogenization of the mixture. Film forming solutions was filtered and $70 \mathrm{~mL}$ of the solution were poured into $15 \mathrm{~cm}$ petri dishes and dried at ambient conditions under laminar flow hood until the solvent was completely evaporated and peeled off after $48 \mathrm{~h}$.

\section{Plasma Treatment}

The experimental schematic for the DBD plasma treatment has been presented in Fig. 1. The DBD plasma source consists of two circular aluminum plate electrodes (outer diameter $=158 \mathrm{~mm})$ over perspex dielectric layers $(10 \mathrm{~mm}$ thickness). The applied voltage to the electrode was obtained from a step-up transformer (Phenix Technologies,

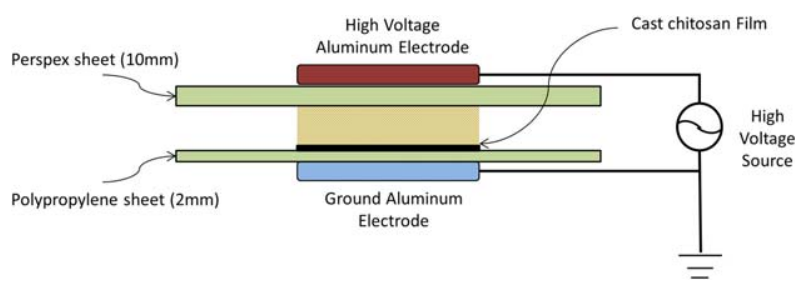

FIG. 1. EXPERIMENTAL SCHEMATIC FOR DBD PLASMA TREATMENT OF CHITOSAN FILMS

Inc., MD). The input voltage to the primary winding was $230 \mathrm{~V}$ at a frequency of $50 \mathrm{~Hz}$. A 2-mm-thick polypropylene sheet was also used to stabilize the discharge. The distance between electrodes was $22 \mathrm{~mm}$. The atmospheric air conditions at the time of treatment were $46 \%$ relative humidity $(\mathrm{RH})$ and $19 \mathrm{C}$. The samples were treated at 60,70 and $80 \mathrm{kV}$ for $1,2,3,4$ and $5 \mathrm{~min}$.

\section{Material Characterization}

Atomic Force Microscopy (AFM). Atomic force microscopy (AFM) measurements were carried out to observe the surface topography of the samples before and after DBD plasma treatment. The AFM used was an MFP-3D BIO 1126 (Asylum Research, Santa Barbara, CA) operated in intermittent contact (tapping) mode. The images were collected at a fixed scan rate of $0.5 \mathrm{~Hz}$. The sampling rate was 512 lines. The data were processed using MF3D software (version $111111+1219)$.

X-ray Photoelectron Spectroscopy. X-ray photoelectron spectroscopy (XPS, K-ALPHA, Thermo Scientific, Barcelona, Spain) was used to analyze sample surface composition. All spectra were collected using $\mathrm{Al}-\mathrm{K} \alpha$ radiation $(1,486.6 \mathrm{eV})$, monochromatized by a twin crystal monochromator, yielding a focused X-ray spot with a diameter of $400 \mu \mathrm{m}$, at $3 \mathrm{~mA} \times 12 \mathrm{kV}$. The alpha hemispherical analyzer was operated in the constant energy mode with survey scan pass energies of $200 \mathrm{eV}$ to measure the whole energy band and $50 \mathrm{eV}$ in a narrow scan to selectively measure the particular elements. XPS was also used to provide the chemical bonding state as well as the elemental composition of the samples. Charge compensation was achieved with the system flood gun that provides low energy electrons and low energy argon ions from a single source.

Contact Angle and Surface Free Energy. Static contact angle of all the films were analyzed using Theta Lite Optical Tensiometer (Attension, TL100, Finland) by sessile drop technique. Water and ethylene glycol were used as test liquids for analysis. A drop of each test liquid was uniformly placed on the film surface and the image was recorded at 15 frames per second for $10 \mathrm{sec}$. Images were analyzed using 
the OneAttension software ( $\mathrm{v} 2.1$ ). All the values reported are the mean of more than 130 data points done in triplicates. Surface free energy ( $S F E$ ) was also analyzed using the same software using Fowkes model.

X-ray Diffraction. Wide-angle X-ray scattering (WAXS) was performed on a Bruker D8-Advance (USA) diffractometer, equipped with a $\mathrm{Cu}-\mathrm{K} \alpha$ radiation source $(\lambda=$ $1.546 \AA$ ), operating at $40 \mathrm{kV}$ and $40 \mathrm{~mA}$ as the applied voltage and current, respectively. The incidence angle $(2 \theta)$ was varied between 5 degree and 90 degree at a scanning rate of 2 degree/min.

Fourier Transform Infrared Spectroscopy. Fourier transform infrared spectroscopy (FTIR)-ATR spectroscopy was carried out by using a Perkin Elmer FTIR/FT-NIR spectrometer (Spectrum 400) from 4000 to $400 \mathrm{~cm}^{-1}$ to measure any changes in the spectra intensities. A background spectrum was collected by keeping the resolution as $4 \mathrm{~cm}^{-1}$. After the background scan, treated and untreated film samples were placed in the sample holder and analyzed.

Water Vapor Transmission Rate. Water vapor transmission rate (WVTR) was measured gravimetrically using the ASTM method E 96/E 96M-05 (ASTM, 2005). Briefly, $50 \mathrm{~g}$ of anhydrous calcium chloride, after drying at $100 \mathrm{C}$ for $24 \mathrm{~h}$, was placed in each test jar to establish dry conditions. Control and plasma treated film samples were placed over the jar, and its edge was sealed using paraffin wax ( $T_{\mathrm{m}}=54-56 \mathrm{C}$; Sigma-Aldrich, Ireland). After the films were mounted, the whole assembly was weighed and placed in a climatic chamber at a set temperature of $24 \pm 1 \mathrm{C}$ and $\mathrm{RH}$ of $50 \pm 1 \%$. The assembly was weighed with an accuracy of $0.001 \mathrm{~g}$ at $24 \mathrm{~h}$ intervals. WVTR was calculated in $\mathrm{g} /\left(\mathrm{m}^{2}\right.$ day $)$ using Eq. (1).

$$
W V T R=\frac{M_{\mathrm{t}}-M_{0}}{\Delta t} \cdot \frac{1}{A}
$$

where $M_{0}$ is the initial mass of the test jar $(\mathrm{g}), M_{\mathrm{t}}$ is the mass of the test jar at time $t(\mathrm{~g}), \Delta t$ is the duration of the test period (day) and $A$ is the effective surface area of the test film $\left(\mathrm{m}^{2}\right)$.

Oxygen Transmission Rate. Oxygen transmission rate (OTR) analysis was conducted with an Oxygen Permeation Analyser 8500 from Systech Instruments (Metrotec S.A., Spain). Treated films were cut into circular samples $(14 \mathrm{~cm}$ diameter) and clamped in the diffusion chamber at $25 \mathrm{C}$. Pure oxygen (99.9\%) was introduced into the upper half of the chamber while nitrogen was injected into the lower half, where an oxygen sensor was placed. The oxygen volumetric flow rate per unit area of the membrane and per time
$\left(O T R, \mathrm{~cm}^{3} /\left(\mathrm{m}^{2}\right.\right.$ day $\left.)\right)$ was continuously monitored until a steady state was reached. All samples were analyzed in triplicates. OTR $R^{\star} e$ values $\left(\mathrm{cm}^{3} \mathrm{~mm} /\left(\mathrm{m}^{2}\right.\right.$ day $\left.\left.^{1}\right)\right)$ were calculated based on film thickness and was used for comparison.

\section{RESULT AND DISCUSSION}

\section{Surface Topography}

The surface topography of control and plasma-treated chitosan film was characterized using AFM. The surface of control chitosan film was observed to be smooth and homogenous without any sharp features with a root mean square roughness of $1.01 \pm 0.96 \mathrm{~nm}$. After DBD plasma treatment, the surface roughness was observed to be increasing with appearance of sharp protuberances (Fig. 2). After DBD plasma treatment for $5 \mathrm{~min}$ at 60,70 and $80 \mathrm{kV}$, root mean square surface roughness of chitosan films were 2.02, 2.82 and $3.39 \mathrm{~nm}$, respectively. The increase in the surface roughness of chitosan films were observed to be significantly less prominent compared to other bio-based polymers like corn starch, zein and caseinate films, when treated under same setup (Pankaj et al. 2014a, in press a,b). The increase in the surface roughness after DBD plasma treatment is mainly due to the etching effects caused by the bombardment of energetic plasma species on the polymer surface. The DBD plasma-treated chitosan films had less pronounced etching effects which may be attributed to the densely packed twofold helical structure of chitosan films (Ogawa et al. 2004).

\section{Surface Composition}

XPS analysis was done to characterize the effects of DBD plasma treatment on the surface chemical composition of the chitosan films. Elemental composition of carbon (C1s) and oxygen (O1s) were recorded on control and DBD plasma-treated film surfaces (Table 1). The control chitosan film has an $\mathrm{O} / \mathrm{C}$ ratio of 0.36 . After DBD plasma treatment, a gradual increase in the surface oxygen content was observed with increase in the treatment voltage levels.

Further analysis of the surface chemistry of control and DBD plasma-treated chitosan films were done by deconvoluting the high resolution C1s peaks. The deconvoluted peaks are presented in Fig. 3. Four C1s peaks were identified at $285,286.6,288.4$ and $289.3 \mathrm{eV}$ which were assigned to $\mathrm{C}-\mathrm{C} / \mathrm{C}-\mathrm{H}, \quad \mathrm{C}-\mathrm{O} / \mathrm{C}-\mathrm{O}-\mathrm{H}, \quad \mathrm{O}-\mathrm{C}-\mathrm{O}$ and $\mathrm{O}=\mathrm{C}-\mathrm{O}$ bonds respectively (Wagner and Muilenberg 1979; Amaral et al. 2005). Significant increases in the $\mathrm{O}-\mathrm{C}-\mathrm{O}$ bonds were observed after DBD plasma treatment which can be linearly correlated with the increase in treatment voltage levels. The $\mathrm{O}-\mathrm{C}-\mathrm{O}$ bond contribution increased from $7.17 \%$ 

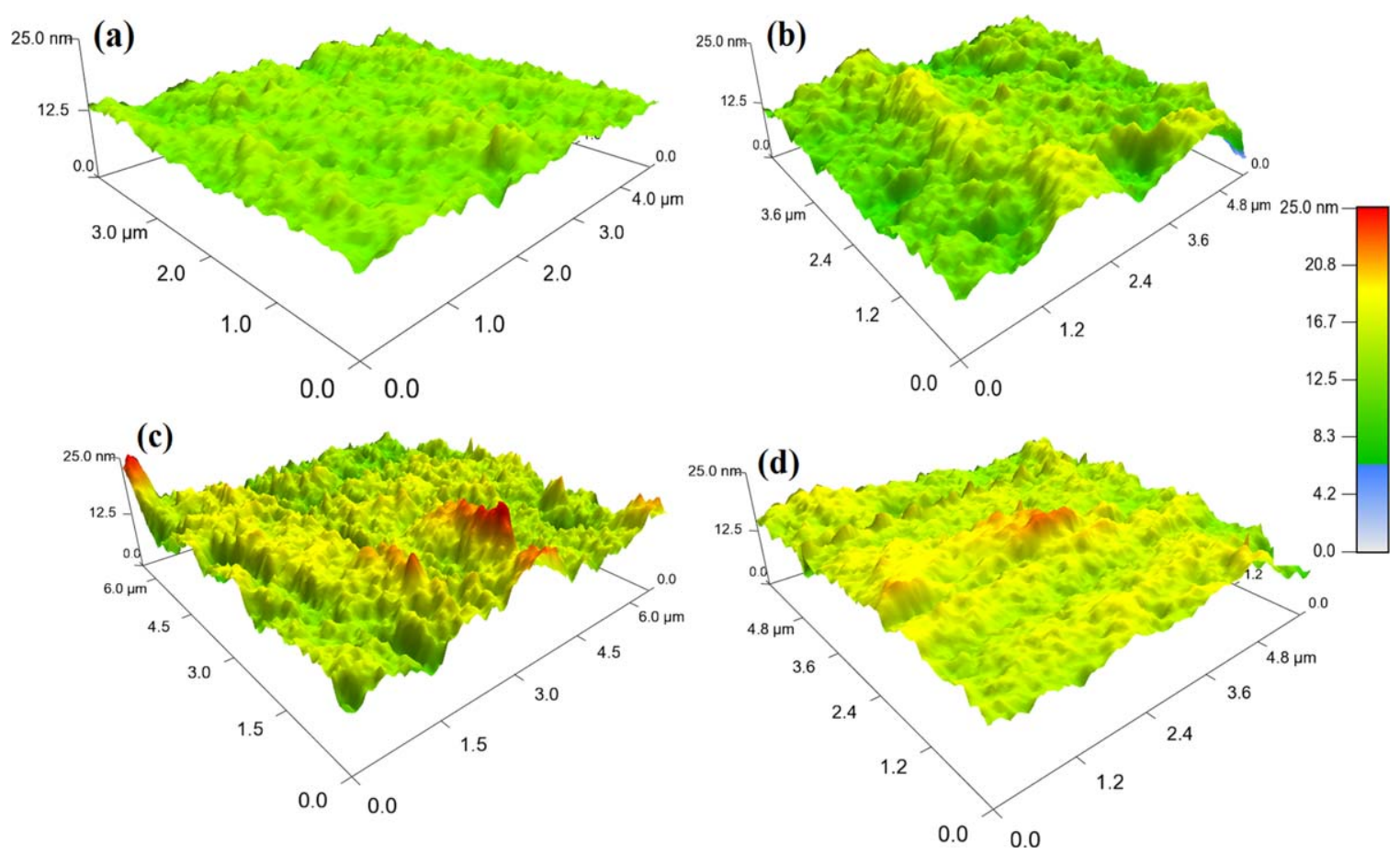

FIG. 2. SURFACE TOPOGRAPHY OF DBD PLASMA-TREATED CHITOSAN FILMS (A) CONTROL, (B) $60 \mathrm{kV}$ for $5 \mathrm{MIN}$, (C) $70 \mathrm{kV}$ for $5 \mathrm{MIN}$, (D) $80 \mathrm{kV}$ for 5 MIN

in control film to $12.45 \%$ after DBD plasma treatment at $80 \mathrm{kV}$ for $5 \mathrm{~min}$. This clearly indicates that DBD plasma treatment of chitosan leads to the formation of more oxygen-containing groups containing $\mathrm{O}-\mathrm{C}-\mathrm{O}$ bonds on the film surface hence increasing the overall surface oxygen content. Similar increase was also observed in other polymers treated under the same setup reported previously (Pankaj et al. in press a,b).

\section{Contact Angle and Surface Free Energy}

Film hydrophilicity is an important characteristic for deciding the packaging application of any polymer. The contact angle was analyzed for the control and plasma treated films and results are shown in Table 2(A). Control chitosan film has a contact angle of 76 degree which was significantly reduced after plasma treatment showing an increase in the hydrophilicity of the film.

TABLE 1. THE ELEMENTAL COMPOSITION AND RATIO OF THE DBD PLASMA TREATED CHITOSAN FILM SURFACE

\begin{tabular}{llll}
\hline Sample & C1s (\%) & O1s (\%) & O/C \\
\hline Control & 73.75 & 26.26 & 0.36 \\
$60 \mathrm{kV}$ for 5 min & 72.81 & 27.19 & 0.37 \\
$70 \mathrm{kV}$ for 5 min & 71.45 & 28.56 & 0.40 \\
$80 \mathrm{kV}$ for 5 min & 66.94 & 33.06 & 0.49 \\
\hline
\end{tabular}

The SFE for the plasma-treated films was also calculated from the contact angle [Table 2(B)]. Fowkes or OwenWendt approach or OWRK equation (Eq. (2)) was used for calculation of total SFE, polar and dispersive components of the SFE using the two test liquids.

$$
\frac{1}{2} \cdot \gamma_{\mathrm{L}}(1+\cos \theta)=\sqrt{\gamma_{\mathrm{S}}^{\mathrm{d}} \cdot \gamma_{\mathrm{L}}^{\mathrm{d}}}+\sqrt{\gamma_{\mathrm{S}}^{\mathrm{p}} \cdot \gamma_{\mathrm{L}}^{\mathrm{p}}}
$$

where $\gamma_{\mathrm{L}}$ is surface tension of liquid, $\theta$ is contact angle, $\gamma^{\mathrm{d}}$ and $\gamma^{\mathrm{P}}$ are dispersive and polar components respectively.

SFE analysis of control and plasma-treated chitosan films shows a significant and linear increase in the total SFE. A significant decrease in the dispersive component and simultaneously, significant increase in the polar component of the SFE was observed. These observations show that DBD plasma treatment of chitosan films increased the amount of polar groups on the film surface, increasing the polar component and total SFE of the films. These results also support the XPS observation which shows an increase in surface oxygen content and possible increase in polar group like $\mathrm{O}-\mathrm{C}-\mathrm{O}$.

\section{X-ray Diffraction}

X-ray diffraction (XRD) was used to study the changes in the chitosan film structure after DBD plasma treatment. 

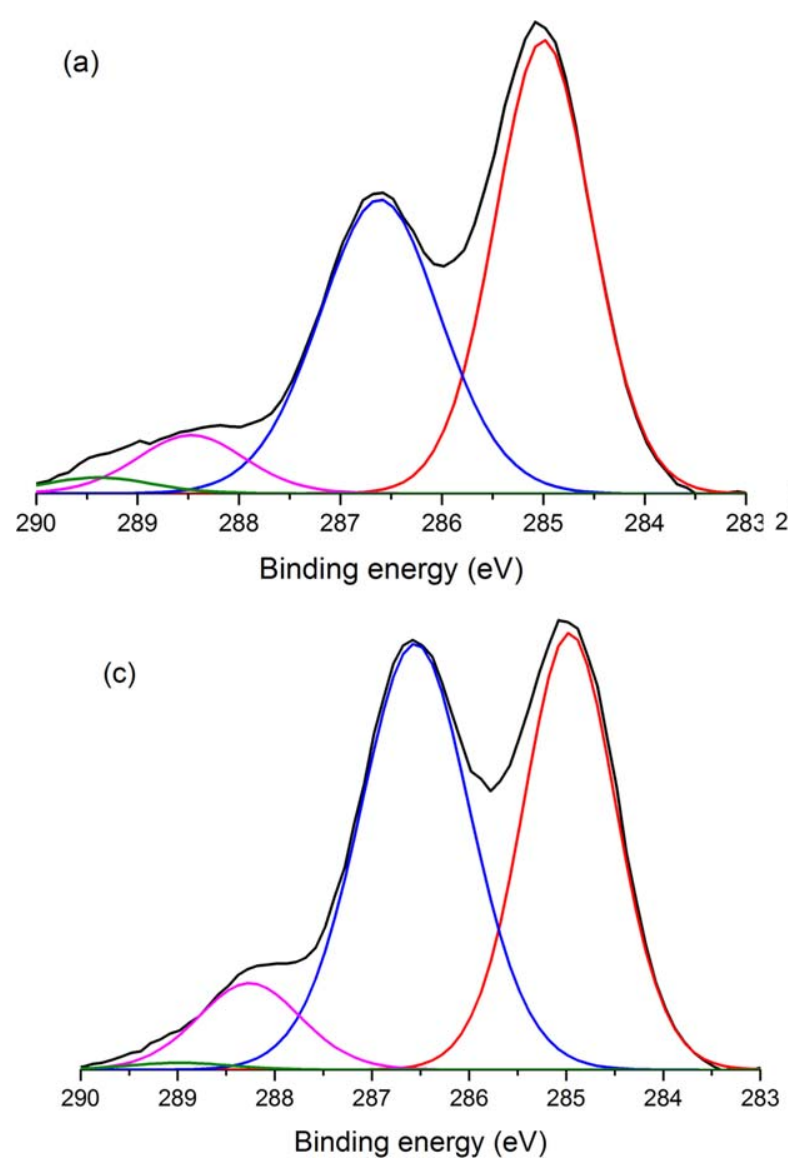

(b)

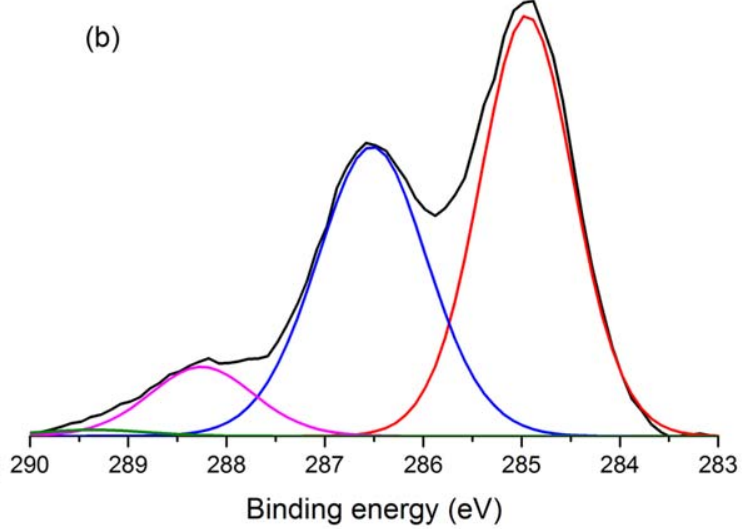

(d)

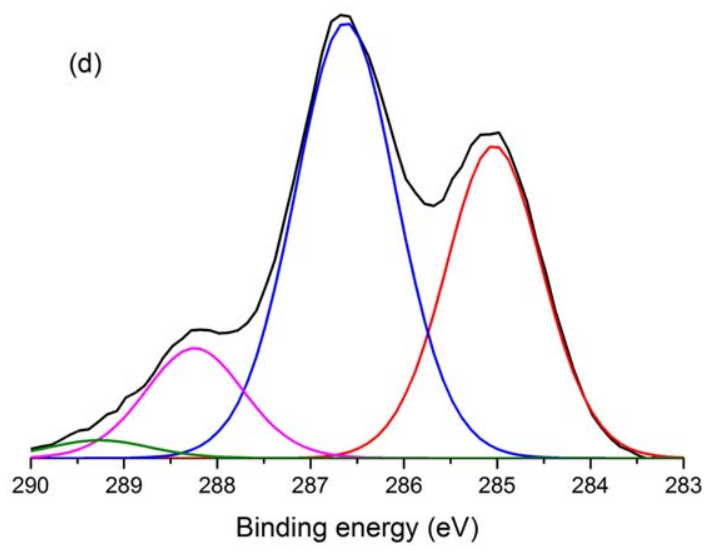

FIG. 3. DECONVOLUTED C1s PEAKS OF CONTROL AND DBD PLASMA-TREATED CHITOSAN FILMS. (A) CONTROL, (B) $60 \mathrm{kV}$ for $5 \mathrm{MIN}$, (C) $70 \mathrm{kV}$ for $5 \mathrm{MIN},(\mathrm{D}) 80 \mathrm{kV}$ for $5 \mathrm{MIN}$

Both control and plasma-treated films have shown only one dominant peak at $2 \theta=20.3$ degree $(d=4.37 \AA$ ) (Fig. 4). This peak corresponds to the "Form II" crystals having a constrained chain conformation (Fan et al. 2009). Form II crystals are orthorhombic having a unit cell of $a=4.40 \AA$, $b=10.0 \AA$ and $c=10.30 \AA$ (fiber axis). Although, no shift in the peak was observed after plasma treatment, the peak intensity was observed to be significantly higher after DBD plasma treatment. This increase in the peak intensity suggests the increase in regularity of the low $d$-spacing structure and development of more compact crystalline form leading to structural compactness of chitosan films after DBD plasma treatment (Qun et al. 2007).

\section{FTIR-ATR}

The spectrum of control and DBD plasma-treated chitosan films showed no change in the characteristic peaks of amide I at $1650 \mathrm{~cm}^{-1}$ ( $\mathrm{C}=\mathrm{O}$ stretching), amide II at $1554 \mathrm{~cm}^{-1}$ $(\mathrm{N}-\mathrm{H}$ in-plane deformation coupled with $\mathrm{C}-\mathrm{N}$ stretching), amide III ( $\mathrm{C}-\mathrm{N}$ stretching coupled with $\mathrm{NH}$ in-plane deformation) and $\mathrm{CH}_{2}$ wagging coupled with $\mathrm{OH}$ in-plane

TABLE 2. CONTACT ANGLE (A) AND SURFACE FREE ENERGY (B) ANALYSIS OF CONTROL AND PLASMA TREATED CHITOSAN FILMS

\begin{tabular}{|c|c|c|c|c|c|}
\hline & Parameters & Control & $60 \mathrm{kV}$ for $5 \mathrm{~min}$ & $70 \mathrm{kV}$ for $5 \mathrm{~min}$ & $80 \mathrm{kV}$ for $5 \mathrm{~min}$ \\
\hline \multicolumn{6}{|l|}{ A. Contact angle } \\
\hline Water & $\theta_{\mathrm{w}}$ & $76.09 \pm 0.71$ & $57.69 \pm 0.23$ & $46.43 \pm 1.80$ & $27.56 \pm 0.07$ \\
\hline Ethylene glycol & $\theta_{\mathrm{e}}$ & $57.68 \pm 1.14$ & $51.54 \pm 1.73$ & $40.21 \pm 1.23$ & $22.42 \pm 0.20$ \\
\hline \multicolumn{6}{|c|}{ B. Surface free energy } \\
\hline \multirow[t]{3}{*}{ Fowkes } & $\gamma^{\text {tot }}$ & 28.83 & 46.86 & 57.94 & 75.33 \\
\hline & $\gamma^{d}$ & 13.38 & 3.64 & 3.58 & 2.84 \\
\hline & $\gamma^{\mathrm{p}}$ & 15.45 & 43.22 & 54.36 & 72.49 \\
\hline
\end{tabular}




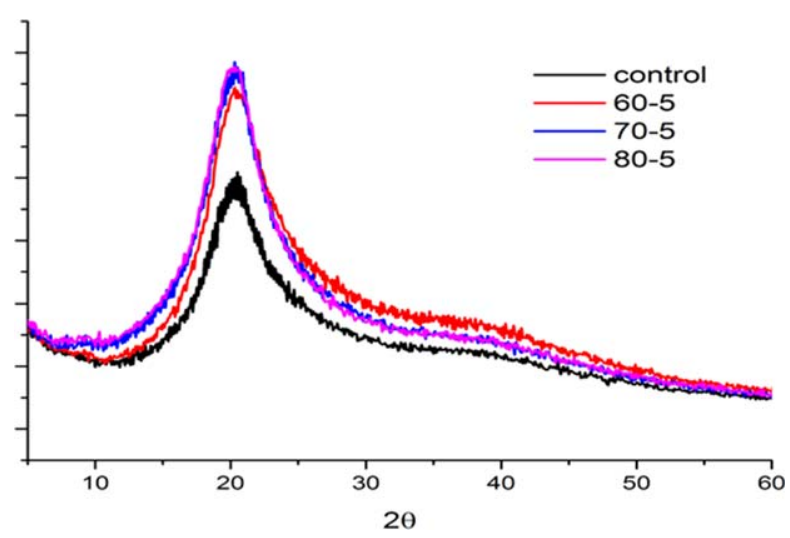

FIG. 4. X-RAY DIFFRACTION PATTERNS OF CONTROL AND DBD PLASMA-TREATED CHITOSAN FILMS

deformation at $1317 \mathrm{~cm}^{-1}$ (Amaral et al. 2005). In the fingerprint region (Fig. 5), peaks were observed at $1150 \mathrm{~cm}^{-1}$ (asymmetric bridge oxygen stretching), 1060 and 1030 $\mathrm{cm}^{-1}$ (C-O stretching in ether group), 990 and $950 \mathrm{~cm}^{-1}$ $\left(\mathrm{CH}_{3}\right.$ rocking), $900 \mathrm{~cm}^{-1}$ ( $\mathrm{C}-\mathrm{O}$ ring stretching), 925 and $850 \mathrm{~cm}^{-1}$ ( $\mathrm{C}-\mathrm{C}$ bond). The increases in the oxygen containing peaks are in good agreement with the results obtained from XPS analysis. It can be concluded from these results that DBD plasma treatment increase the oxygen content of the chitosan film without any significant change in the amide bonds.

\section{Water Vapor and Oxygen Permeability}

Water vapor and oxygen permeability are important barrier properties for any polymer and it is desired that any new processing technology should not adversely change the barrier properties of the packaging films. WVTR of control chitosan film was found to be $37.32 \pm 1.53 \mathrm{~g} /\left(\mathrm{m}^{2}\right.$ day $)$. No

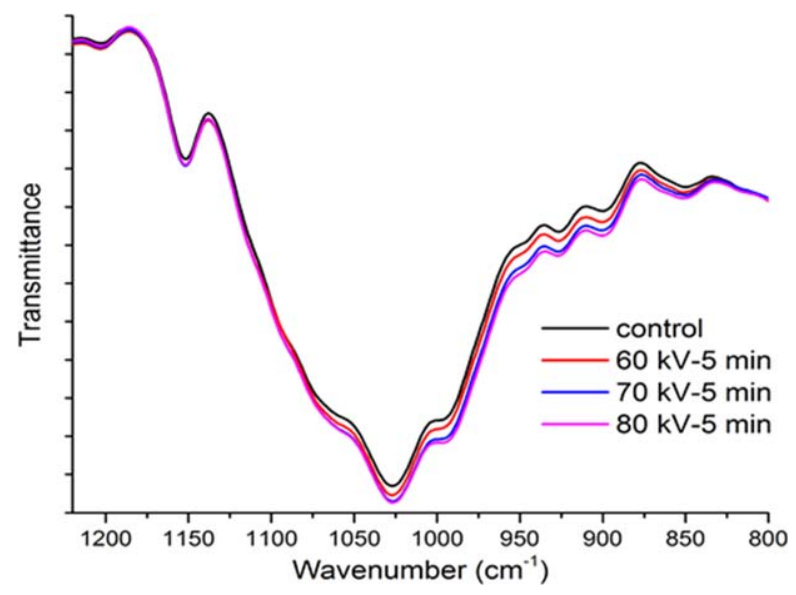

FIG. 5. FTIR-ATR SPECTRA OF CONTROL AND DBD PLASMA-TREATED CHITOSAN FILMS significant difference $(P>0.05)$ was observed in the WVTR of DBD plasma-treated films all voltage levels and treatment times. $O T R^{\star} e$ of control chitosan film was observed to be $0.17 \pm 0.11 \mathrm{~cm}^{3} \mathrm{~mm} /\left(\mathrm{m}^{2}\right.$ day $)$ and no significant difference $(P>0.05)$ were observed after the plasma treatment for all treatment voltages and times. These results are particularly important for potential application of chitosan films and to fit in as a competitive commercial food packaging material for DBD plasma processing.

\section{CONCLUSION}

DBD plasma treatment of chitosan films increased its surface roughness. However, the surface etching by plasma was found significantly less compared to other biopolymer. XRD results also demonstrated an increase in the structural compactness of plasma-treated chitosan films. XPS and FTIR spectra confirm the increase in the oxygen containing groups in the chitosan film after plasma treatment. The increase in the polar component of SFE resulted in the significant increase in the film hydrophilicity. However, no significant change was observed in barrier properties of the chitosan film after DBD plasma treatment. These results indicates that chitosan films are more robust for use along with DBD plasma treatment and serve as good potential to be used for plasma processed products.

\section{REFERENCES}

AIDER, M. 2010. Chitosan application for active bio-based films production and potential in the food industry: Review. LWT - Food Sci. Technol. 43, 837-842.

AMARAL, I.F., GRANJA, P.L. and BARBOSA, M.A. 2005. Chemical modification of chitosan by phosphorylation: An XPS, FT-IR and SEM study. J. Biomater. Sci. Polym. Ed. 16, 1575-1593.

ASTM. 2005. Standard Test Methods for Water Vapour Transmission of Materials, American Society for Testing of Materials (ASTM), West Conshohocken, PA.

BASTOS, D.C., SANTOS, A.E.F., DA SILVA, M.L.V.J. and SIMÃO, R.A. 2009. Hydrophobic corn starch thermoplastic films produced by plasma treatment. Ultramicroscopy 109, 1089-1093.

CHANG, S.-H. and CHIAN, C.-H. 2013. Plasma surface modification effects on biodegradability and protein adsorption properties of chitosan films. Appl. Surf. Sci. 282, 735-740.

DU, J.M., GEMMA, H. and IWAHORI, S. 1997. Effects of chitosan coating on the storage of peach, Japanese pear, and kiwifruit. J. Jpn. Soc. Horticult. Sci. 66, 15-22.

EL GHAOUTH, A., ARUL, J., PONNAMPALAM, R. and, BOULET, M. 1991a. Chitosan coating effect on storability and quality of fresh strawberries. J. Food Sci. 56, 1618-1620. 
EL GHAOUTH, A., ARUL, J., PONNAMPALAM, R. and BOULET, M. 1991b. Use of chitosan coating to reduce water loss and maintain quality of cucumber and bell pepper fruits. J. Food Process. Preserv. 15, 359-368.

EL GHAOUTH, A., PONNAMPALAM, R., CASTAIGNE, F. and ARUL, J. 1992. Chitosan coating to extend the storage life of tomatoes. HortScience 27, 1016-1018.

FAN, M., HU, Q. and SHEN, K. 2009. Preparation and structure of chitosan soluble in wide $\mathrm{pH}$ range. Carbohydr. Polym. 78, 66-71.

FERREIRA, C.O., NUNES, C.A., DELGADILLO, I. and LOPES-DA-SILVA, J.A. 2009. Characterization of chitosan-whey protein films at acid pH. Food Res. Int. 42, 807-813.

JIANG, Y. and LI, Y. 2001. Effects of chitosan coating on postharvest life and quality of longan fruit. Food Chem. 73, 139-143.

LECETA, I., GUERRERO, P., IBARBURU, I., DUEÑAS, M.T. and DE LA CABA, K. 2013. Characterization and antimicrobial analysis of chitosan-based films. J. Food Eng. 116, 889-899.

LEROUX, F., CAMPAGNE, C., PERWUElZ, A. and GENGEMBRE, L. 2008. Polypropylene film chemical and physical modifications by dielectric barrier discharge plasma treatment at atmospheric pressure. J. Colloid Interface Sci. 328, 412-420.

OGAWA, K., YUI, T. and OKUYAMA, K. 2004. Three D structures of chitosan. Int. J. Biol. Macromol. 34, 1-8.

PANKAJ, S.K., MISRA, N.N. and CULLEN, P.J. 2013. Kinetics of tomato peroxidase inactivation by atmospheric pressure cold plasma based on dielectric barrier discharge. Innov. Food Sci. Emerg. Technol. 19, 153-157.

PANKAJ, S.K., BUENO-FERRER, C., MISRA, N.N., BOURKE, P. and CULLEN, P.J. 2014a. Zein film: Effects of dielectric barrier discharge atmospheric cold plasma. J. Appl. Polym. Sci. 131, 40803.

PANKAJ, S.K., BUENO-FERRER, C., MISRA, N.N., MILOSAVLJEVIĆ, V., O’DONNELL, C.P., BOURKE, P.,
KEENER, K.M. and CULLEN, P.J. 2014b. Applications of cold plasma technology in food packaging. Trends Food Sci. Technol. 35, 5-17.

PANKAJ, S.K., BUENO-FERRER, C., MISRA, N.N., O’NEILL, L., JIMÉNEZ, A., BOURKE, P. and CULLEN, P.J. 2014c. Surface, thermal and antimicrobial release properties of plasma-treated Zein films. J. Renew. Mater. 2, 77-84.

PANKAJ, S.K., BUENO-FERRER, C., MISRA, N.N., O’NEILL, L., JIMÉNEZ, A., BOURKE, P. and CULLEN, P.J. 2014d. Characterization of polylactic acid films for food packaging as affected by dielectric barrier discharge atmospheric plasma. Innov. Food Sci. Emerg. Technol. 21, 107-113.

PANKAJ, S.K., BUENO-FERRER, C., MISRA, N.N., O’NEILL, L., TIWARI, B.K., BOURKE, P. and CULLEN, P.J. 2014. Physicochemical characterization of plasma-treated sodium caseinate film. Food Res. Int. 66, 438-444.

PANKAJ, S.K., BUENO-FERRER, C., MISRA, N., O'NEILL, L., TIWARI, B., BOURKE, P. and CULLEN, P. 2015. Dielectric barrier discharge atmospheric air plasma treatment of high amylose corn starch films. LWT - Food Sci. Technol. 63(2), 1076-1082.

QUN, G., AJUN, W. and YONG, Z. 2007. Effect of reacetylation and degradation on the chemical and crystal structures of chitosan. J. Appl. Polym. Sci. 104, 2720-2728.

SIMPSON, B.K., GAGNÉ, N., ASHIE, I.N.A. and NOROOZI, E. 1997. Utilization of chitosan for preservation of raw shrimp (Pandalus borealis). Food Biotechnol. 11, 25-44.

UPADHYAY, D.J., CUI, N.-Y., ANDERSON, C.A. and BROWN, N.M.D. 2004. Surface oxygenation of polypropylene using an air dielectric barrier discharge: The effect of different electrode-platen combinations. Appl. Surf. Sci. 229, 352-364.

VAN DEN BROEK, L.A.M., KNOOP, R.J.I., KAPPEN, F.H.J. and BOERIU, C.G. 2015. Chitosan films and blends for packaging material. Carbohydr. Polym. 116, 237-242.

WAGNER, C. and MUILENBERG, G. 1979. Handbook of X-ray Photoelectron Spectroscopy, Perkin-Elmer, Waltham, MA. 